\title{
THE FEMALE PARAPLEGIC: A STATISTICAL SURVEY
}

By R. Girard, M.D., D. Boisson, M.D., J. Depassio, M.D., M. H. BouCAND, M.D. and M. EysseTte, M.D.

University of Lyon, Hôpital Henry Gabrielle, 69230 Saint Genis Laval, France.

Summary. From November 1969 to December I979, I 234 patients with spinal cord lesions were treated at the Henry Gabrielle Hospital. Of these 386 were from medical causes and 848 from trauma. The computer study of these cases brings out statistical differences between the sexes as the overall incidence in females is 30 per cent and even lower if one considers traumatic cases only 22.4 per cent out of the 848 cases. Furthermore, the average female paraplegic is two years older and it was noted that more females are married. In females the causes of spinal cord injuries are more frequently car accidents and suicidal falls from high places, whereas in males the causes are related to direct blows, that is sport injuries, motorcycle accidents and industrial falls.

Clinical symptoms are similar in the two groups with the exception that there is less heterotopic ossifications and fewer bladder stones in females. The duration of hospitalisation is shorter in females. A well equipped household is more important for the handicapped females than for males.

Key words: Spinal cord lesions; Epidemiology; Female paraplegics; Sexual distribution.

\section{The Population and its Statistical Survey}

THE COMPUTERIZED statistical survey of all tetraplegic and paraplegic patients admitted to the Henry Gabrielle Hospital has been carried out since the opening of the specialized wards for spinal cord lesions in November 1969 up to December I979. The first results concerning 35 I traumatic cases were presented by P. Minaire at the Annual Scientific Meeting of the International Medical Society of Paraplegia held in Stoke Mandeville Hospital in 1977.

Castanier (I978) studied the first 783 cases with a computer, and Demolin (I98I) completed this work for I234 cases. Of these, 848 were traumatic (69 per cent) and 386 non-traumatic (3 I per cent), 72.8 per cent of the patients living in the Rhône-Alpes region, 26.6 per cent from the remaining parts of France and 0.6 per cent were foreign patients.

\section{Sex distribution}

There are more men than women, the figures being 865 men ( 70 per cent) and 369 ( 30 per cent), with a ratio of $2 \cdot 3$ men for I woman. This difference is even more marked when only traumatic cases are considered, with 77.6 per cent being men, and 22.4 per cent women or 3.46 men for I woman. The non-traumatic cases have a ratio of I I 5 men for each woman.

The normal population ratio for the same region is nearly $I$ to $I$.

This male prevalence is a well known fact already reported by many authors (Table I). 
TABLE I

Sex distribution of spinal cord lesions

\begin{tabular}{llrrl}
\hline & & Females & Males & $\begin{array}{l}\text { M/F } \\
\text { ratio }\end{array}$ \\
\hline Gehrig (I968) & Switzerland & 93 & 46 I & $4 \cdot 96$ \\
Frankel (I969) & England & 69 & 593 & $8 \cdot 59$ \\
Jousse (I967) & Canada & I23 & 842 & $6 \cdot 85$ \\
Kassa (I967) & Norway & 6 & 36 & 6 \\
Key (I970) & South Africa & 32 & 268 & $8 \cdot 38$ \\
Kraus (I975) & California & 68 & 252 & $3 \cdot 7$ \\
Sutton (I973) & Australia & 30 & 210 & $7 \cdot 07$ \\
Tusji (I975) & Japan & I I & I06 & $9 \cdot 64$ \\
DeVivo(I980) & U.S.A. & 348 & I5I7 & $4 \cdot 35$ \\
Carter (I980) & Texas & I97 & 967 & $4 \cdot 8$ \\
& Traumatic cases & I90 & 658 & $3 \cdot 46$ \\
Our study & Medical causes & I80 & 206 & I. I5 \\
& Total & 368 & 862 & $2 \cdot 3$ \\
\hline
\end{tabular}

\begin{abstract}
Age
In Table II the cases are distributed according to their age. In males there is a high incidence between the age of $15-25$ years which is not so obvious in females. Kraus (1975) reported similar findings. The female's average age is two years higher and at the time of occurrence of the spinal lesion there are more married women than married men.
\end{abstract}

\title{
Aetiology and sex
}

There is no difference in aetiology for medical paraplegics amongst men and women but on the contrary there is a difference of aetiology for traumatic paraplegia.

As would be expected, occupational injuries occur usually in an industrial environment. High risk jobs are filled by men, therefore, the direct blow injury is more frequent in men than in women ( 9 per cent compared with I. 7 per cent).

The same is true for accidental falls at work, and of 92 accidents 89 were men and only three women. Of the remaining i i 7 falls occurring outside the working area 79 were men and 28 women (Table III). Traffic accidents present different data because women are equally exposed as men. But a greater number of women are injured in car collisions; 77 out of 272 total cases. Kraus (1975) drew the same conclusion. Of all traffic accidents only 0.6 per cent involve pedestrians and there is no sexual difference. Special attention must be given to motorcycle crashes. Frankel (I969) found 20.I per cent in England and Minaire (I977) I 5.4 per cent in France, much higher than in the United States (Kraus (I975) 5.3 per cent, Carter (I977) 2.9 per cent. Minaire showed a male predominence of 68 men compared with five women. In our additional study carried out for the last three years, this male predominence is less marked, a ratio 
TABLE II

Age and sex distribution for traumatic patients

\begin{tabular}{lcl}
\hline Years & $\begin{array}{c}\text { Male/female } \\
\text { this study }\end{array}$ & $\begin{array}{c}\text { ratio } \\
\text { Kraus }\end{array}$ \\
\hline \multicolumn{1}{c}{ I5 } & I $\cdot 4$ & $\mathrm{I} \cdot 5$ \\
I $5-25$ & $4 \cdot 0 \mathrm{I}$ & $3 \cdot 74$ \\
$25-35$ & $3 \cdot 52$ & $4 \cdot 4 \mathrm{I}$ \\
$35-45$ & $4 \cdot 06$ & $4 \cdot 43$ \\
$45-55$ & $3 \cdot 9 \mathrm{I}$ & 8 \\
$55-65$ & $2 \cdot 22$ & $3 \cdot 42$ \\
over 65 & $\mathrm{I} \cdot 8 \mathrm{I}$ & $\mathbf{I} \cdot 66$ \\
All cases & $3 \cdot 45$ & $3 \cdot 70$ \\
\hline
\end{tabular}

TABLE III

Sex and aetiology for traumatic cases

\begin{tabular}{|c|c|c|c|c|c|}
\hline & Females & Males & $\begin{array}{l}\mathrm{M} / \mathrm{F} \\
\text { ratio }\end{array}$ & Total & $\%$ \\
\hline Car & 77 & 195 & $2 \cdot 53$ & 272 & $32 \cdot 2$ \\
\hline Motorcycles & I 4 & 103 & $7 \cdot 35$ & I 17 & I3.8 \\
\hline Accidental falls & 30 & I 79 & 5.96 & 209 & $24 \cdot 7$ \\
\hline Suicidal falls & 32 & I3 & 0.4 & 45 & $5 \cdot 3$ \\
\hline Direct blow & 3 & 47 & $15 \cdot 6$ & 50 & 5.9 \\
\hline diving & 0 & 25 & & 25 & 3 \\
\hline Sports $\}$ others & 6 & 20 & $3 \cdot 33$ & 26 & $3 \cdot I$ \\
\hline Gunshot wounds & 2 & 19 & $9 \cdot 5$ & $2 I$ & $2 \cdot 5$ \\
\hline Others & 26 & 57 & $2 \cdot 19$ & 83 & $9 \cdot 5$ \\
\hline Total & 190 & 658 & 3.46 & 848 & 100 \\
\hline
\end{tabular}

of 35 men compared with nine women. This is explained by an increased number of women using motorcycles.

The overall sport incidence includes 5 I cases, 45 men and six females. All 25 diving accidents were males.

Gunshot injuries are rare in Europe but more frequent in the U.S.A.: I 2.3 per cent in California, Kraus (1975), and I4 per cent in Texas, Carter (1977). In our study there were 21 cases of which these were 19 men and two women.

Of particular interest are the suicidal cases as we previously reported in 1980 , and which our present study confirms.

Suicidal attempt by jumping accounted for 45 injuries, 32 of the women being less than 30 years of age. Accidental falls at work caused mostly high and permanent lesions and involved men. Suicidal falls usually caused a low lesion, which tended to improve.

\section{Level of lesions}

Regarding level of lesion, there is no sex difference except a slightly higher 
female incidence for the lumbosacral level, 7.6 per cent females compared with $\mathbf{I} \cdot 9$ per cent males; this is due to the high incidence of low lesions by suicidal falls. Jousse (I967) and Kraus (I975) reported a similar sexual distribution.

\section{Complications}

Both renal calculi and heterotopic ossification were marginally less frequent in the female group of traumatic urinary lesions; lithiasis was seen in $19 \cdot 7$ per cent of men and I I.5 per cent of women $(p<0.05)$. The statistical difference was even more marked concerning ossification, with 33.7 per cent for men and 25.7 per cent for women with $\mathrm{p}<0.02$.

Our statistical survey points out that urinary lithiasis is all the more frequent if the patient is a man, confined to bed for at least 3 months, and having a urinary tract infection.

\section{Duration of hospitalisation}

The duration of hospitalisation for traumatic lesions was 249 days for males and 226 days for females. Many explanations are possible: the higher incidence of lithiasis and ossification and the greater severity of postaccidental falls prolong the hospital stay of men.

Further hospitalisation due to complications have the same incidence in both sexual groups. Sooner or later about a third are re-hospitalised.

In conclusion, we wish to emphasize that a paraplegic woman's return to her household is very important and complex. In addition to special toilet and bathroom facilities a woman needs a specially equipped kitchen.

Young paraplegic mothers need special equipment and arrangements to take care of their children.

\section{RÉSUMÉ}

I234 lésions médullaires ont été traitées à l'hôpital Henry Gabrielle en II ans (janvier 1969-décembre 1979). L'étude statistique comparative en fonction du sexe, montre certaines différences significatives concernant la fréquence globale; $30 \%$ de femmes, taux qui chute à $22,4 \%$ quand on ne retient que les lésions traumatiques; concernant l'âge puisque les femmes sont en moyenne plus âgées de 2 ans, avec une courbe des âges plus étalée.

Les différences étiologiques sont précises: peu de chutes accidentelles et peu de chocs directs chez les femmes; ces causes sont d'ailleurs souvent en relation avec des accidents professionnels. De même, les accidents de sport et de moto touchent surtout les jeunes hommes, (avec cependant un accroissement de chutes de moto chez les jeunes femmes, au cours des dernières années). A l'opposé, les chutes suicidaires sont surtout féminines.

Les complications de lithiase rénale et d'ossifications hétérotopiques sont moins fréquentes chez les femmes dont le séjour hospitalier moyen est un peu moins long.

Enfin, l'adaptation du logement doit être plus complète pour la femme paraplégique que pour l'homme.

\section{ZUSAMMENFASSUNG}

Die Aufschlüsselung von 1234 Querschnittslähmungen am Henry Gabrielle Krankenhaus vom Januar 1969 bis zum Dezember I979, wurde mittels eines Computers durchgefürt.

Sexuelle Untherschiede sind folgende: $30 \%$ aller Fälle sind Frauen: Nur $22.4 \%$ für die traumatischen Fälle.

Das Frauen-Durchschnittsalter ist 2 Jahre höher. Aethiologische Unterschiede sind: die Berufsunfälle, wie die Motorradunfälle, Direkte Schläge sind selten. 
Im Gegensatz Verletzung en bei Selbstmordversuchen durch Sprung in die Tiefe haben bei Frauen eine günstigere Prognose.

Nierensteine und heterotopische Ossifikationen sind häufiger. Der Krakenaufenthalt der Frau ist etwas kürzer.

Die Wohnungsabänderungen, sind bei der paraplegischen Frau anspruchsvoller.

\section{REFERENCES}

CARTER, R. E. (I977). Etiology of traumatic spinal cord injury: statistic of more than I 100 cases. Texas Med, 73, 6I-65.

Castanier, M. (1978). Etude statistique des traumatismes médullaires de Henry Gabrielle. Thèse, Lyon.

Demolin, D. (I98I). Les blessés médullaires. Etude statistique de I 234 cas dont 848 traumatiques en II ans. Thèse Lyon.

DeVivo, M. \& Fine, P. R. (1980). The prevalence of spinal cord injuries. SCI Digest, Vol. I, winter issue.

Frankel, H. L., Hancok, D. O., Hyslop, G., Melzak, J., Michaelis, L. S., Ungar, G. M., Vernon, J. D. \& Walsh, J. J. (I969). The value of postural reduction in the initial management of closed injuries of the spine with paraplegia and tetraplegia. Paraplegia, 7, I79-192.

GeHrig, R. \& MichaELIS, L. S. (I968). Statistics of acute paraplegia and tetraplegia on a national scale: Switzerland I960-67. Paraplegia, 5, 93-95.

Girard, R., Minaire, P., Castanier, M., Berard, E. \& Perrin-Leriche, B. (I980). Spinal cord injury by falls: comparison between suicidal and accidental cases. Paraplegia, I8, $38 \mathrm{I}-385$.

Jousse, A. T., Wynne-Jones, M. \& Breithaupt, D. J. (I967). A follow-up study of life expectancy and mortality in traumatic transverse myelitis. Proc. I6th Annual Clinical S.C.I. Conf., V. A. Hosp., Long Beach, California, Sep. 27-29, pp. I98-202.

Kraus, J. F., Franti, C. E., Riggins, R. S., Richards, D. \& Bormani, N. O. (1975). Incidence of traumatic spinal cord lesions. F. Chron. Dis., 28, 47 I-492.

Minaire, P., Castanier, M., Girard, R., Berard, E., Deidier, C. \& Bourret, J. (I977). Epidemiology of spinal cord injury in Rhône-Alpes France. Paraplegia, I6, 76-87.

Sutron, N. G. (1973). Injuries of the Spinal Cord. The Management of Paraplegia and Tetraplegia. p. 185. Butterworth, London.

Tusji, S. \& Fujishama, H. (1975). Paraplegias, Clinical Statistics (unpublished data). Kyushu Rosai Hosp., Departments of Orthopaedics and Neurology, Fukuoka, Japan. 